\section{Scientific and technological capabilities in health-related areas: opportunities, challenges, and interactions with the industrial sector}

\author{
Capacitação científica e tecnológica na área \\ da saúde: oportunidades, desafios e formas \\ de articulação com a base produtiva
}

\section{Capacitación científica y tecnológica en el área de la salud: oportunidades, desafíos y formas de colaboración con la base productiva}

Marco Antonio Vargas 1 Jorge Britto 1

\begin{abstract}
Characterization of the scientific and technological infrastructure in health and its interactions with the industrial sector provides key elements for understanding the dynamics of innovation in health. This study conducts an exploratory analysis of the potentialities and limitations associated with scientific and technological capabilities in the health area in Brazil and the different links between the scientific and industrial sectors in health. The analysis points to important growth in internationally indexed research output, especially in certain areas such as pharmaceutics, public health, genetics, morphology, physiology, and microbiology. There has also been important growth in research groups that interact with the industrial sector in selected areas of health. The study highlights the importance of building more solid and permanent bridges between companies, research institutions, and the health system, linking the knowledge developed in research institutions to the dynamics of the industrial sector in health.
\end{abstract}

Scientific Research and Technological Development; Policies and Cooperation in Science, Technology and Innovation; Scientific Publication Indicators; Sustainable Development; Innovation

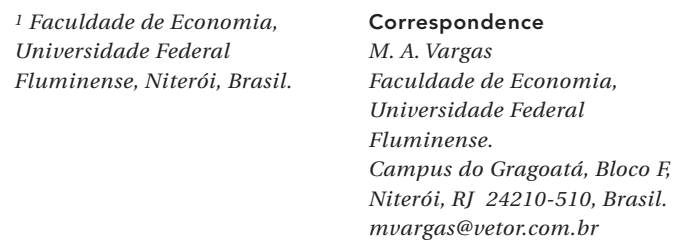

1 Faculdade de Economia, Universidade Federal

Fluminense, Niterói, Brasil. 


\section{Introduction}

Innovations in the health field show strong interaction with the process of basic research that is fed by the science sector. Knowledge generated on the basis of the scientific and technological infrastructure in health feed a flow of important innovations that tend to shape the operation of health services and medical practice themselves, through the use of new medicines, medical equipment and devices, and clinical procedures. Meanwhile, medical practice also plays a central role in medical innovation, since it constitutes the origin of important flows of information that feed new scientific research agendas 1,2 .

Various authors have highlighted the importance of Brazil's health research effort. A result of this process has been significant growth in the number of research groups and researchers involved in health research, as well as a greater share of Brazilian scientific publications in the health area in the world total of publications in this area $3,4,5$. An analysis of the scientific and technological infrastructure in the health area and its different links to the Brazilian National Innovation System in Health is thus important for understanding the dynamics of the innovation process in health. However, one of the main challenges for the dynamics of innovation in the health area in Brazil is the mismatch between the degree of scientific capability and the limited capacity for innovation today in the health industry, defined as the concept of Health EconomicIndustrial Complex (HEIC) 6,7,8.

This study provides an exploratory analysis of the potentialities and limitations of the health science, technology, and innovation infrastructure in Brazil, based on three important aspects in the dynamics of competency-building in this area. The first is the recent dynamism of Brazil's international research output in health. The second is competency-building in strategic areas of knowledge for innovation in health. The third involves the intensity and nature of interactions between companies and research groups in the health field. Particular relevance is assigned to research areas with the potential to spawn new products and processes in health inputs, the strengthening of which is strategic to the HEIC and has been the object of a comprehensive, interlinked set of support policies in Brazil.

\section{Methodological aspects}

Mapping scientific and technological competencies in the health field requires identification of strategic areas of knowledge, considering the increasingly interdisciplinary nature of scientific research and innovation in health. This characteristic appears in three aspects of the effort at mapping competencies, discussed next: (1) the diversity of fields of scientific research capable of generating relevant new knowledge for innovation in health; (2) the diversity of fields of knowledge related to training professional health researchers; and (3) the intensity of cooperation between the scientific and industrial sectors, aimed at fostering knowledge transfer and integration of competencies to accelerate innovative processes.

A broad definition of health research encompasses the "major areas" of Biological and Health Sciences. Since the current analysis focuses primarily on mapping competencies in areas with a more direct impact on innovation leading to new products and processes in health inputs, we selected a specific set of eleven areas: (1) Biophysics; (2) Biochemistry; (3) Pharmacology; (4) Physiology; (5) Genetics; (6) Immunology; (7) Microbiology; (8) Morphology; (9) Parasitology; (10) Pharmaceutics; and (11) Public Health/ Epidemiology. The latter was included due to its importance in providing relevant orientation for key advances in other areas, besides its potential linkage with the industrial sector and its importance for follow-up and evaluation of science and technology policy in health.

The analysis of the dynamics of competency-building in the health area addressed three aspects. First, to evaluate Brazil's participation in international knowledge flows, we considered the information on the country's research output in internationally indexed journals, by area of knowledge, available on the database of the SCImago Journal \& Country Rank, an institution specialized in this type of survey. Information in this database covers 1996-2013, which allowed capturing details on the Brazil's research output in health within the overall framework of international research output. We analyzed differences between the following areas of health research in the SCImago Journal \& Country Rank: (i) Biochemistry, Genetics, and Molecular Biology; (ii) Health Professions; (iii) Immunology and Microbiology; (iv) Materials Science; (v) Medicine; (vi) Neuroscience; (vii) Nursing; and (viii) Pharmacology, Toxicology, and Pharmaceutics. In addition, in the field of research output, we analyzed the data from the Brazilian National Research Council (CNPq) Directory of Research Groups on the publishing output of Brazilian researchers in international journals, based on the classification of the eleven "critical areas" previously mentioned.

Second, to evaluate the process of human resources training and formation of research 
groups in health-related scientific fields, we drew on the CNPq and Brazilian Graduate Studies Coordinating Board (Capes) databases, using the methodology adopted by the authors in previous studies 6 on scientific and technological capability in health. An important source was the data from the CNPq Directory of Research Groups for the Census years (biannual between 2000 and 2010, and again in 2014). The data on "critical areas" of competency-building for innovation in health are compared to the total for the major areas of Biological and Health Sciences and overall research output. We followed the same type of procedure for the data survey in Capes pertaining to the above-mentioned areas, referring to the number of graduate degrees awarded, and specifying $\mathrm{PhD}$ degrees. The data were systematized by areas for the last years in which this information was available from $\mathrm{CNPq}$ or Capes.

Third, to evaluate the intensity of different interactions between companies and research groups in health, we drew on another source of information, also taken from the database of the CNPq Directory of Research Groups, on interaction between health research groups and the industrial sector, covering the number of established relations, the number of companies involved, and the total number of relations established between them. An important proviso is that the information on research group/company interaction (with regard to the frequency of types of relations) may represent a redundant count for both the research groups (the same group could be tabulated in up to three types of interactions) and the companies (the same company mentioned by more than one group is tabulated as many times as it is mentioned). Even acknowledging this limitation, the information on interactive groups, companies involved in interactions, and total number of interactions is important for identifying differences in the pattern and dynamism of these linkages in the various areas involving competency-building for innovation in health.

\section{Results}

\section{Evolution of Brazil's research output in health: scientific publications}

The analysis of the growth in the number of Brazil's international scientific publications in the health area involved the selection of eight specific fields of competency: (i) Biochemistry, Genetics, and Molecular Biology; (ii) Health Professions; (iii) Immunology and Microbiology; (iv) Materials Science; (v) Medicine; (vi) Neuroscience; (vii)
Nursing; and (viii) Pharmacology, Toxicology, and Pharmaceutics. Table 1 shows the evolution in Brazil's research output in absolute terms and in its relative share of world scientific production.

For the set of the above-mentioned selected areas, Brazil's internationally indexed research output grew 418\% between 1996 and 2013, for a mean annual growth rate of $10.4 \%$ during the period analyzed. This growth was lower than the mean annual growth rate of Brazil's internationally indexed research output as a whole, which was $11.6 \%$ during the same period (1996-2013). The areas with high growth featured Health Professions, Nursing, and Medicine, which showed mean annual growth rates in 1996-2013 of $28.3 \%$, $24.5 \%$, and $11.8 \%$, respectively. The areas with the lowest mean annual growth were Neuroscience (7.6\%), Immunology and Microbiology (7.8\%), and Pharmacology, Toxicology, and Pharmaceutics $(7.93 \%)$.

Table 1 also allows evaluating the selected areas' share of Brazil's total internationally indexed research output. This emphasizes the selected areas' high share of Brazil's total research output. Together, in 1996, these eight areas accounted for nearly half of all Brazilian scientific publications in the SCImago database $(47.6 \%)$. This share dropped to $40.2 \%$ in 2013 , of which $19 \%$ for Medicine, 7.5\% for Biochemistry, Genetics, and Molecular Biology, 3.5\% for Materials Science, and $2.8 \%$ for Immunology and Microbiology.

In 1996, Brazil detained less than $1 \%(0.81 \%)$ of all scientific publications in the world in the selected health areas. By 2005 this share had increased to $1.51 \%$, and in 2013 it reached $2.22 \%$, reflecting greater participation by Brazilian scientific publications in the field of health, based on the volume of internationally indexed publications. The areas with the largest increase in Brazil's share of international scientific production featured Immunology and Microbiology (3.46\% in 2013), Nursing (3.19\%), Health Professions (3.17\%), Neuroscience (2.64\%), and Pharmacology, Toxicology, and Pharmaceutics (2.47\%).

We also evaluated the country's research output in "critical areas" for innovation in health, considering publication in international journals by researchers affiliated with research groups in these areas, based on data from the CNPq Directory of Research Groups for 2000-2010, as shown in Table 2. This table shows that from 2000 to 2010 , publication increased $468 \%$ in these research areas, compared to $560 \%$ for the major areas of Biological and Health Sciences as a whole and $333 \%$ for all the research areas included in that survey.

Disaggregation of the data by selected research areas shows that they concentrated $50.1 \%$ 
Table 1

Evolution of Brazil's research output in selected health areas, in number of publications and percentage share, $1996-2013$.

\begin{tabular}{|c|c|c|c|c|c|}
\hline & $\begin{array}{c}1996 \\
n\end{array}$ & $\begin{array}{c}2005 \\
n\end{array}$ & $\begin{array}{c}2010 \\
n\end{array}$ & $\begin{array}{c}2013 \\
n\end{array}$ & $\begin{array}{c}\text { Mean annual growth } 1996-2013 \\
\%\end{array}$ \\
\hline \multicolumn{6}{|l|}{ Research output } \\
\hline Biochemistry, Genetics, and Molecular Biology & 1,472 & 2,845 & 4,998 & 6,692 & 9.6 \\
\hline Health Professions & 41 & 197 & 884 & 1,222 & 28.3 \\
\hline Immunology and Microbiology & 724 & 1,303 & 2,078 & 2,494 & 7.8 \\
\hline Materials Science & 854 & 2,264 & 3,131 & 3,125 & 8.9 \\
\hline Medicine & 2,674 & 6,791 & 14,262 & 16,876 & 11.8 \\
\hline Neuroscience & 517 & 967 & 1,681 & 1,725 & 7.6 \\
\hline Nursing & 46 & 290 & 1,196 & 1,486 & 24.5 \\
\hline Pharmacology, Toxicology, and Pharmaceutics & 576 & 1,195 & 1,803 & 2,134 & 8.4 \\
\hline Subtotal & 6,904 & 15,852 & 30,033 & 35,754 & 10.4 \\
\hline \multirow[t]{2}{*}{ Total } & 14,496 & 37,967 & 75,739 & 89,009 & 11.6 \\
\hline & $\%$ & $\%$ & $\%$ & $\%$ & \\
\hline \multicolumn{6}{|l|}{ Share of total research output in Brazil } \\
\hline Biochemistry, Genetics, and Molecular Biology & 10.2 & 7.5 & 6.6 & 7.5 & \\
\hline Health Professions & 0.3 & 0.5 & 1.2 & 1.4 & \\
\hline Immunology and Microbiology & 5.0 & 3.4 & 2.7 & 2.8 & \\
\hline Materials Science & 5.9 & 6.0 & 4.1 & 3.5 & \\
\hline Medicine & 18.4 & 17.9 & 18.8 & 19.0 & \\
\hline Neuroscience & 3.6 & 2.5 & 2.2 & 1.9 & \\
\hline Nursing & 0.3 & 0.8 & 1.6 & 1.7 & \\
\hline Pharmacology, Toxicology, and Pharmaceutics & 4.0 & 3.1 & 2.4 & 2.4 & \\
\hline Subtotal & 47.6 & 41.8 & 39.7 & 40.2 & \\
\hline \multirow[t]{2}{*}{ Total } & 100.0 & 100.0 & 100.0 & 100.0 & \\
\hline & $\%$ & $\%$ & $\%$ & $\%$ & \\
\hline \multicolumn{6}{|l|}{ Share of world total research output } \\
\hline Biochemistry, Genetics, and Molecular Biology & 0.86 & 1.51 & 1.94 & 2.14 & \\
\hline Health Professions & 0.25 & 0.83 & 2.45 & 3.17 & \\
\hline Immunology and Microbiology & 1.78 & 2.75 & 3.22 & 3.46 & \\
\hline Materials Science & 0.71 & 1.25 & 1.45 & 1.34 & \\
\hline Medicine & 0.66 & 1.38 & 2.15 & 2.24 & \\
\hline Neuroscience & 1.40 & 2.43 & 2.96 & 2.64 & \\
\hline Nursing & 0.24 & 1.09 & 2.76 & 3.19 & \\
\hline Pharmacology, Toxicology, and Pharmaceutics & 1.24 & 2.19 & 2.31 & 2.47 & \\
\hline Subtotal & 0.81 & 1.51 & 2.12 & 2.22 & \\
\hline Total & 0.79 & 1.40 & 1.99 & 2.21 & \\
\hline
\end{tabular}

Source: prepared by the authors based on data from SCImago Journal \& Country Rank.

of research publication in health and $41.5 \%$ of all science output with international circulation. The selected areas featured Biochemistry (6.2\% of total output), Genetics (6\%), Pharmaceutics (5.1\%), Microbiology (4.3\%), and Public Health (4.2\%). The areas with the most growth in research publication with international circulation in 2000-2010 were Pharmaceutics (987\% growth), Public Health (738\%), Genetics (615\%), and Morphology (517\%). 
Evolution of research groups and human resources training for innovation in health

The CNPq database can be used to measure the recent evolution in health research groups and their affiliated researchers for the years 2000 , 2010, and 2014, shown in Table 3. In 2014, the eleven selected areas accounted for $10.9 \%$ of the research groups and $12 \%$ of the researchers surveyed in the CNPq Directory of Research Groups. Broadening the analysis to encompass the major areas of Biological and Health Sciences, these proportions increase to $27.2 \%$ of research groups and $29.1 \%$ of researchers. The 11 selected areas also recorded $148 \%$ growth in the number of groups between 2000 and 2014, compared to $159 \%$ for the major areas of Biological and Health Sciences and $201 \%$ for all areas. In terms of the number of researchers, growth in the 11 areas was higher, reaching $253 \%$ from 2000 to 2014 , compared to $222 \%$ for the major areas of Biological and Health Sciences and $245 \%$ for all areas.

The areas with the most relevant weight were Public Health (2.8\% of all the groups), Biochemistry $(1.3 \%)$, Pharmaceutics (1.3\%), and Genetics $(1.2 \%)$. The areas with the largest growth in groups were Pharmaceutics (351\% growth from 2000 to 2014) and Public Health (237\%). In terms of number of researchers, the areas with the greatest weight were Public Health $(3.5 \%$ of all the researchers), Pharmaceutics (1.4\%), Genetics (1.4\%), and Biochemistry (1.3\%). The areas with the largest growth in number of researchers were Pharmaceutics (400\% growth from 2000 to 2014), Public Health (318\%), Physiology (263\%), and Genetics (262\%).

As shown in Table 3, from 2000 to 2013 the number of graduate degrees awarded in the selected areas increased from 1,718 to 4,421 , or growth of $157 \%$, compared to $167 \%$ in the major areas of Biological and Health Sciences and 183\% overall growth in graduate studies degrees during the same period. The share of the 11 selected areas in the total degrees awarded reached $8.1 \%$ in 2013. For PhD degrees specifically, Table 3 shows that from 2000 to 2013, the number of PhDs awarded in the selected areas increased from 509 to 1,291 , or a growth of $154 \%$, compared to $162 \%$ in the major areas of Biological and Health Sciences and $187 \%$ overall growth in $\mathrm{PhD}$ degrees during the same period. Of the 11 selected areas, six stood out due to the fact that in 2013, each awarded more than 100 PhDs: Public Health (225 PhDs), Pharmaceutics (212), Biochemistry (201), Genetics (170), Physiology (137), and Microbiology (116). The areas with the largest increases in PhDs awarded from 2000 to 2013 were Pharmaceutics $(657 \%)$, Immunology (273\%), Microbiology (263\%), Physiology (226\%), and Public Health (159\%).

International publication in areas of health knowledge, 2000-2010.

\begin{tabular}{|c|c|c|c|c|c|}
\hline & 2000 & 2006 & 2010 & 2010 & $\begin{array}{c}\text { Growth, } \\
2000-2010\end{array}$ \\
\hline & $\mathbf{n}$ & $\mathbf{n}$ & $\mathbf{n}$ & $\%$ of total & $\%$ \\
\hline Biophysics & 997 & 2,825 & 4,450 & 1.3 & 346 \\
\hline Biochemistry & 4,597 & 15,325 & 21,001 & 6.2 & 357 \\
\hline Pharmacology & 2,688 & 8,665 & 12,860 & 3.8 & 378 \\
\hline Physiology & 1,981 & 6,427 & 10,078 & 3.0 & 409 \\
\hline Genetics & 2,855 & 11,513 & 20,404 & 6.0 & 615 \\
\hline Immunology & 1,901 & 5,789 & 9,135 & 2.7 & 381 \\
\hline Microbiology & 2,900 & 8,757 & 14,541 & 4.3 & 401 \\
\hline Morphology & 1,332 & 4,864 & 8,222 & 2.4 & 517 \\
\hline Parasitology & 2,345 & 5,478 & 9,127 & 2.7 & 289 \\
\hline Pharmaceutics & 1,598 & 9,511 & 17,375 & 5.1 & 987 \\
\hline Public Health & 1,695 & 7,299 & 14,196 & 4.2 & 738 \\
\hline Selected areas & 24,889 & 86,453 & 141,389 & 41.5 & 468 \\
\hline Biological and Health Sciences & 42,759 & 164,261 & 282,014 & 82.8 & 560 \\
\hline Total & 78,626 & 224,541 & 340,577 & 100.0 & 333 \\
\hline
\end{tabular}

Source: prepared by the authors based on data from the Brazilian National Research Council (CNPq) Directory of Research Groups. 
Table 3

Evolution of research groups and researchers (2000-2014) and total graduate degrees and PhDs awarded (2000-2013) in strategic areas for innovation in health.

\begin{tabular}{|c|c|c|c|c|c|c|c|c|c|c|}
\hline & \multicolumn{5}{|c|}{ Groups } & \multicolumn{5}{|c|}{ Researchers } \\
\hline & 2000 & 2010 & 2014 & 2014 & Growth & 2000 & 2010 & 2014 & 2014 & Growth \\
\hline & & & & & $2000-2014$ & & & & & $2000-2014$ \\
\hline & $\mathrm{n}$ & $\mathrm{n}$ & $\mathrm{n}$ & $\%$ & $\%$ & $\mathrm{n}$ & $\mathrm{n}$ & $\mathrm{n}$ & $\%$ & $\%$ \\
\hline Biophysics & 46 & 74 & 80 & 0.20 & 74 & 184 & 477 & 591 & 0.30 & 221 \\
\hline Biochemistry & 210 & 381 & 475 & 1.30 & 126 & 936 & 2,617 & 2,984 & 1.30 & 219 \\
\hline Pharmacology & 107 & 178 & 231 & 0.70 & 116 & 529 & 1,350 & 1,635 & 0.70 & 209 \\
\hline Physiology & 110 & 196 & 250 & 0.70 & 127 & 430 & 1,242 & 1,561 & 0.70 & 263 \\
\hline Genetics & 189 & 376 & 417 & 1.20 & 121 & 862 & 3,028 & 3,123 & 1.40 & 262 \\
\hline Immunology & 101 & 163 & 186 & 0.50 & 84 & 480 & 1,133 & 1,353 & 0.60 & 182 \\
\hline Microbiology & 179 & 300 & 365 & 1.00 & 104 & 903 & 2,246 & 2,524 & 1.10 & 180 \\
\hline Morphology & 109 & 200 & 226 & 0.60 & 107 & 405 & 1,157 & 1,336 & 0.60 & 230 \\
\hline Parasitology & 115 & 171 & 193 & 0.50 & 68 & 576 & 1,252 & 1,459 & 0.60 & 153 \\
\hline Pharmaceutics & 103 & 385 & 465 & 1.30 & 351 & 631 & 3,087 & 3,154 & 1.40 & 400 \\
\hline Public Health & 289 & 732 & 975 & 2.80 & 237 & 1,914 & 6,576 & 8,003 & 3.50 & 318 \\
\hline Selected areas & 1,558 & 3,156 & 3,863 & 10.90 & 148 & 7,850 & 24,165 & 27,723 & 12.00 & 253 \\
\hline All health areas & 3,790 & 8,179 & 9,828 & 27.70 & 159 & 20,847 & 61,784 & 67,063 & 29.10 & 222 \\
\hline \multirow[t]{4}{*}{ Total } & 11,760 & 27,523 & 35,424 & 100.00 & 201 & 66,804 & 205,445 & 230,558 & 100.00 & 245 \\
\hline & \multicolumn{5}{|c|}{ Graduate degrees (total) } & \multicolumn{5}{|c|}{ PhDs } \\
\hline & 2000 & 2008 & 2013 & 2013 & Variation & 2000 & 2008 & 2013 & 2013 & Variation \\
\hline & $n$ & $\mathrm{n}$ & $n$ & $\%$ & $\%$ & $\mathrm{n}$ & $\mathrm{n}$ & $\mathrm{n}$ & $\%$ & $\%$ \\
\hline Biophysics & 61 & 100 & 55 & 0.10 & -10 & 26 & 46 & 25 & 0.20 & -4 \\
\hline Biochemistry & 288 & 403 & 487 & 0.70 & 69 & 118 & 191 & 201 & 1.30 & 70 \\
\hline Pharmacology & 143 & 496 & 912 & 1.40 & 538 & 28 & 111 & 212 & 1.40 & 657 \\
\hline Physiology & 120 & 215 & 249 & 0.40 & 108 & 31 & 81 & 76 & 0.50 & 145 \\
\hline Genetics & 136 & 319 & 402 & 0.60 & 196 & 42 & 116 & 137 & 0.90 & 226 \\
\hline Immunology & 244 & 420 & 448 & 0.70 & 84 & 81 & 130 & 170 & 1.10 & 110 \\
\hline Microbiology & 67 & 107 & 154 & 0.20 & 130 & 15 & 44 & 56 & 0.40 & 273 \\
\hline Morphology & 123 & 207 & 305 & 0.50 & 148 & 32 & 79 & 116 & 0.80 & 263 \\
\hline Parasitology & 56 & 149 & 47 & 0.10 & -16 & 11 & 48 & 27 & 0.20 & 145 \\
\hline Pharmaceutics & 87 & 112 & 136 & 0.20 & 56 & 38 & 41 & 46 & 0.30 & 21 \\
\hline Public Health & 393 & 741 & 1,226 & 1.90 & 212 & 87 & 157 & 225 & 1.50 & 159 \\
\hline Selected areas & 1,718 & 3,269 & 4,421 & 6.80 & 157 & 509 & 1,044 & 1,291 & 8.40 & 154 \\
\hline All health areas & 5,948 & 10,733 & 15,858 & 24.20 & 167 & 1,695 & 3,197 & 4,442 & 29.10 & 162 \\
\hline Total & 23,139 & 46,725 & 65,428 & 100.00 & 183 & 5,318 & 10,711 & 15,287 & 100.00 & 187 \\
\hline
\end{tabular}

Source: prepared by the authors based on data from the Brazilian National Research Council (CNPq) Directory of Research Groups and Georeferenced Information System of the Brazilian National Graduate Studies Coordinating Board (GEO-Capes; http://geocapes.capes.gov.br/geocapes2/).

\section{Types of interactions with the industrial sector}

Another issue is the intensity of interactions between the industrial sector and the various areas of health research. We incorporated this aspect into our analysis by reviewing data published in the CNPq Directory of Research Groups on relations between groups working in various health research areas and the industrial sector. The focus on the selected areas is due to their capacity to generate knowledge that can help spawn innovative new products and processes in health, which reinforces their strategic nature.

Information on overall evolution of research groups in the selected areas and on groups with interactive relations in 2002-2014, as shown in 
Table 4, indicates that in 2014, the 11 selected areas accounted for 1,310 interactive groups ( $14 \%$ of the interactive groups covered in the Census). Among the selected areas, those with the most interactive groups in 2014 were Public Health (278), Genetics (171), Biochemistry (168), Microbiology (149), and Pharmaceutics (147). From 2010 to 2014 , the selected areas grew by an impressive $308 \%$ in the total number of interactive groups, compared to $244 \%$ for health areas as a whole, and $167 \%$ for all areas. Among the 11 selected areas, the largest growth was in Physiology (775\%), Parasitology (680\%), Morphology (564\%), Biophysics (500\%), and Immunology (371\%). From 2010 to 2014 , interactive groups as a share of all the groups increased from $10 \%$ to $34 \%$, meaning a larger increase than for health areas as a whole and for all areas. Among the selected areas, this proportion was highest in Genetics (41\%), Microbiology (41\%), Parasitology (40\%), and Pharmacology (37\%). Among the selected areas, the largest growth was in Parasitology (591\%), Physiology (586\%), Morphology (487\%), and Biophysics (455\%).

The available data in the CNPq Directory of Research Groups for the last year (2014) do not allow disaggregating the number of companies with which they establish relations, or the total relations of research groups according to the selected areas. To address this issue, we focused on the available data from the 2010 Census, as well as the growth in these indicators from 2002 to 2010, shown in Table 5. In 2010, the 321 groups with linkages in the selected areas established relations with 543 companies. As a whole the areas selected as strategic for innovation in health accounted in 2010 for $10.2 \%$ of the companies linked to research groups and tabulated in the 2010 Census and for $7.1 \%$ of the relations involved. Thus, despite recent growth in the number of groups with these interactions, the number of companies and interactions with the selected areas showed low percentages. The areas linked to the most companies were Public Health (108 companies), Pharmaceutics (106), Biochemistry (96), and Genetics (94). The areas with the most interactions were Pharmaceutics (207), Public Health (172), Biochemistry (160), Genetics (152), and Microbiology (101).

Interactive research groups as a proportion of all research groups in 2010 represented $10.2 \%$ for the 11 selected areas, compared to $10.7 \%$ for health areas as a whole and $12.7 \%$ for the Census database as a whole. Among the various selected

Total number of research groups and interactive research groups in areas of health knowledge, 2002, 2010, and 2014.

\begin{tabular}{|c|c|c|c|c|c|c|c|c|c|c|c|c|}
\hline & \multicolumn{3}{|c|}{2002} & \multicolumn{3}{|c|}{2010} & \multicolumn{3}{|c|}{2014} & \multicolumn{3}{|c|}{ Variation $2010-2014$} \\
\hline & $\begin{array}{c}\text { Groups in } \\
\text { area (B) }\end{array}$ & $\begin{array}{l}\text { Groups with } \\
\text { interactions } \\
\text { (A) }\end{array}$ & A/B & $\begin{array}{c}\text { Groups in } \\
\text { area (B) }\end{array}$ & $\begin{array}{l}\text { Groups with } \\
\text { interactions } \\
\text { (A) }\end{array}$ & $A / B$ & $\begin{array}{c}\text { Groups in } \\
\text { area (B) }\end{array}$ & $\begin{array}{l}\text { Groups with } \\
\text { interactions } \\
\text { (A) }\end{array}$ & $A / B$ & $\begin{array}{c}\text { Groups in } \\
\text { area (B) }\end{array}$ & $\begin{array}{l}\text { Groups with } \\
\text { interactions } \\
\text { (A) }\end{array}$ & $\mathrm{A} / \mathrm{B}$ \\
\hline & $\mathbf{n}$ & $\mathrm{n}$ & $\%$ & $\mathrm{n}$ & $\mathrm{n}$ & $\%$ & $\mathrm{n}$ & $\mathrm{n}$ & $\%$ & $\%$ & $\%$ & $\%$ \\
\hline Biophysics & 60 & 3 & 5.0 & 74 & 4 & 5.4 & 80 & 24 & 30.0 & 8 & 500 & 455 \\
\hline Biochemistry & 274 & 14 & 5.1 & 381 & 40 & 10.5 & 475 & 168 & 35.4 & 25 & 320 & 237 \\
\hline Pharmacology & 124 & 9 & 7.3 & 178 & 26 & 14.6 & 231 & 86 & 37.2 & 30 & 231 & 155 \\
\hline Physiology & 136 & 4 & 2.9 & 196 & 8 & 4.1 & 250 & 70 & 28.0 & 28 & 775 & 586 \\
\hline Genetics & 249 & 15 & 6.0 & 376 & 50 & 13.3 & 417 & 171 & 41.0 & 11 & 242 & 208 \\
\hline Immunology & 119 & 4 & 3.4 & 163 & 14 & 8.6 & 186 & 66 & 35.5 & 14 & 371 & 313 \\
\hline Microbiology & 220 & 19 & 8.6 & 300 & 40 & 13.3 & 365 & 149 & 40.8 & 22 & 273 & 206 \\
\hline Morphology & 130 & 1 & 0.8 & 200 & 11 & 5.5 & 226 & 73 & 32.3 & 13 & 564 & 487 \\
\hline Parasitology & 133 & 4 & 3.0 & 171 & 10 & 5.8 & 193 & 78 & 40.4 & 13 & 680 & 591 \\
\hline Pharmaceutics & 171 & 23 & 13.5 & 385 & 55 & 14.3 & 465 & 147 & 31.6 & 21 & 167 & 121 \\
\hline Public Health & 388 & 10 & 2.6 & 732 & 63 & 8.6 & 975 & 278 & 28.5 & 33 & 341 & 231 \\
\hline Selected areas & 2,004 & 106 & 5.3 & 3,156 & 321 & 10.2 & 3,863 & 1,310 & 33.9 & 22 & 308 & 233 \\
\hline All health areas & 4,919 & 274 & 5.6 & 8,179 & 879 & 10.7 & 9,828 & 3,027 & 30.8 & 20 & 244 & 187 \\
\hline Totals & 15,158 & 1,279 & 8.4 & 27,523 & 3,506 & 12.7 & 35,424 & 9,348 & 26.4 & 29 & 167 & 107 \\
\hline Selected areas (\%) & 13.2 & 8.3 & 62.7 & 11.5 & 9.2 & 79.8 & 10.9 & 14.0 & 128.5 & & & \\
\hline All health areas (\%) & 32.5 & 21.4 & 66.0 & 29.7 & 25.1 & 84.4 & 27.7 & 32.4 & 116.7 & & & \\
\hline
\end{tabular}

Source: prepared by the authors based on data from the Brazilian National Research Council (CNPq) Directory of Research Groups. 
Number of interactive research groups, number of companies with which they maintained interactions, and total interactions by health area, total in 2010 .

\begin{tabular}{|c|c|c|c|c|c|}
\hline & Groups & Companies & Interactions & $\begin{array}{c}\text { Interactive groups/Total } \\
\text { groups }\end{array}$ & $\begin{array}{c}\text { Companies/ } \\
\text { Interactive group } \\
-2010\end{array}$ \\
\hline & $\mathrm{n}$ & $\mathbf{n}$ & $\mathbf{n}$ & $\%$ & $\%$ \\
\hline Biophysics & 4 & 5 & 7 & 5.4 & 1.3 \\
\hline Biochemistry & 40 & 96 & 160 & 10.5 & 2.4 \\
\hline Pharmacology & 26 & 31 & 46 & 14.6 & 1.2 \\
\hline Physiology & 8 & 8 & 12 & 4.1 & 1.0 \\
\hline Genetics & 50 & 94 & 152 & 13.3 & 1.8 \\
\hline Immunology & 14 & 20 & 24 & 8.6 & 1.3 \\
\hline Microbiology & 40 & 66 & 101 & 13.3 & 1.6 \\
\hline Morphology & 11 & 15 & 26 & 5.5 & 1.4 \\
\hline Parasitology & 10 & 12 & 22 & 5.8 & 1.2 \\
\hline Pharmaceutics & 55 & 106 & 207 & 14.3 & 1.8 \\
\hline Public Health & 63 & 108 & 172 & 8.6 & 1.7 \\
\hline Selected areas & 321 & 561 & 929 & 10.2 & 1.7 \\
\hline Biological and Health & 879 & 1,497 & 2,625 & 10.7 & 1.6 \\
\hline \multicolumn{6}{|l|}{ Sciences } \\
\hline Total & 3,506 & 5,510 & 13,113 & 12.7 & 1.9 \\
\hline Areas (\%) & 9.2 & 10.2 & 7.1 & 0.80 & 0.89 \\
\hline Health (\%) & 25.1 & 27.2 & 20.0 & 0.84 & 0.86 \\
\hline
\end{tabular}

Source: prepared by the authors based on data from the Brazilian National Research Council (CNPq) Directory of Research Groups.

areas, this proportion was highest for Pharmacology (14.6\%), Pharmaceutics (14.3\%), Microbiology (13.3\%), and Genetics (13.3\%). As for the number of companies per interactive group, the selected areas showed a figure of 1.7 , similar to that for health areas as a whole (1.6) and lower than for the Census database as whole (1.9). Among the selected areas, this indicator was highest for Biochemistry (2.4), Pharmaceutics (1.8), Genetics (1.8), and Public Health (1.7).

\section{Discussion}

The analysis of Brazil's science, technology, and innovation infrastructure in health points to some important characteristics. First, the evolution in the production of internationally indexed research articles in health shows important growth in the country's research output in certain areas, like Nursing, Health Professions, and Medicine. Such growth was less intense in other health areas like Immunology and Microbiology, Neuroscience, and Materials Science. The percentage share in 2013 was highest in Immunol- ogy and Microbiology, Nursing, Health Professions, and Neuroscience.

Next, the health area as a whole shows considerable weight in Brazil's total research production with international circulation, accounting for as much as $82.8 \%$ of the total tabulated by the CNPq Directory of Research Groups in 2010. Of the 11 selected areas, the ones with the greatest weight were Biochemistry (6.2\% of total production), Genetics (6\%), Pharmaceutics (5.1\%), Microbiology (4.3\%), and Public Health (4.2\%), while the areas that experienced the highest growth in published research output were Pharmaceutics (987\% growth during the period analyzed), Public Health (738\%), Genetics (615\%), and Morphology (517\%). The increasing connection between these areas and international knowledge flows strengthens their strategic relevance for innovation in health.

Third, from 2000 to 2014 there was an impressive growth in the number of research groups in the health area and in the number of affiliated researchers in absolute terms, even though the selected areas' share of the total for all health areas and of the overall total of research groups and 
researchers tabulated by the $\mathrm{CNPq}$ Directory of Research Groups remained relatively constant. Among the selected strategic areas, those with the greatest dynamism in all the groups were Pharmaceutics and Public Health. The first clearly has an applied nature in inducing the generation of innovations for health inputs, while the latter features the possibility of linking these innovations to demands raised by the country in health and sanitation. The growth in the number of researchers from 2000 to 2014 was led by the areas of Pharmaceutics, Public Health, Genetics, Physiology, and Morphology. The number of PhD degrees awarded in the selected areas increased from 509 in 2000 to 1,291 in 2013, or the equivalent of $154 \%$ growth. Among the selected areas, the most new PhDs were in the areas of Public Health, Pharmaceutics, Biochemistry, and Genetics, and the areas with the largest growth in the number of PhDs awarded from 2000 to 2013 were Pharmaceutics, Immunology, Microbiology, Physiology, and Public Health.

Fourth, the analysis of the types of linkages between research groups and the industrial sector in the areas most directly related to progress in knowledge in the health area shows the highest numbers of interactive groups in Public Health, Genetics, Biochemistry, Microbiology, and Pharmaceutics. From 2010 to 2014, the selected areas witnessed an impressive $308 \%$ growth in the total number of interactive groups, particularly featuring the increase in Physiology, Parasitology, Morphology, Biophysics, and Immunology. Interactive groups as a proportion of total research groups in the selected areas reached 34\% in 2014, higher than for all health areas and for all areas of science, with a lead role by Genetics, Microbiology, Parasitology, and Pharmacology.

Despite the growth in interactive research groups and scientific output in health, the evidence suggests that this growth did not lead directly to greater linkage with the industrial sector responsible for developing innovations for the market. While the selected "critical areas" for innovation in health accounted for $41 \%$ of the participation in international journals in $2010,11 \%$ of the groups (in 2014) and $14 \%$ of the interactive groups (also 2014) pointed to a proportion of $10.2 \%$ of companies linked to research groups in those areas (data from 2010). In this sense, as evidence of the immature nature of Brazilian National Innovation System in Health, authors like Guimarães 4,5 and Albuquerque \& Cassiolato 9 point to the predominance of progress in knowledge in the academic environment, versus the private industrial sector's relatively small share. This emphasizes the importance of knowledge developed in research institutions for increasing the dynamism of the health industrial complex, especially its biotechnological components such as medicine, vaccines, and diagnostic devices.

While interaction is still limited between academia and companies in the health area with a view towards innovation, such interaction has increased in recent years, for various reasons: the universities' need for external financing, companies' need for external knowledge, improvement in Brazil's legislation (e.g., the Innovation Law of 2004), and recent measures by the Federal Government (like the creation of Brazilian Company for Industrial Research and Innovation - Embrapii and the National Knowledge Platforms Program).

The results point to the important growth of research groups with linkages to the industrial sector in the selected areas, showing positive signs in comparison to the previous situation, when growth in these groups was disconnected from the industrial sector responsible for the development of innovations for the market. This process tends to intensify due to the strategic importance of advances in key fields of technical and scientific knowledge and the growing sophistication of research and development (R\&D) activities needed to generate innovations. Strengthening these linkages is an important mechanism for the development of technical and productive competencies in strategic areas of the health industrial complex. Furthermore, the accumulation of capabilities with levels of excellence in key scientific areas in health in Brazil - illustrated by the growth of such areas' share in total international publications - may serve as a factor for strengthening innovative capabilities, as long as they are linked to the industrial sector for the development of new products and processes.

\section{Conclusions}

Knowledge transfer between the scientific and industrial sectors has become increasingly relevant in the health area for various reasons. The knowledge generated based through the scientific and technological infrastructure in the health area feeds a flow of important innovations, which tend to shape the operation of health services and medical practices themselves, through the use of new medicines, medical equipment and devices, and clinical procedures.

First, this knowledge transfer facilitates the development of products and services that allow treating various problems related to the specificities of plant health in Brazil. Next, strengthening these linkages provides an important mechanism for the dynamics of various activities comprising 
the health industrial complex, allowing the development of technical-industrial competencies in strategic areas. Third, Brazil's accumulation of capabilities with levels of excellence in key scientific areas in health can serve as a factor for strengthening innovative capabilities, as long as they are linked to the industrial sector for the development of new products and processes. The analysis shows that the country has a broad range of institutions with consolidated research groups in health. The importance of this scientific infrastructure appears in the country's growing and relevant share of research output as measured by publication in internationally indexed journals. However, a critical issue for Brazil's participation in new strategic technological platforms for innovation in health is to overcome the existing mismatch between the degree of scientific capability and the limited capacity for innovation in the industrial sector, which thus requires increasing the dynamics of linkages between the National Innovation System in Health and the HEIC.

The results indicate important growth in research groups with linkages to the industrial sector in the selected areas, with some positive signs compared to the previous situation. It is important to continue, extend, and expand existing policies in order to build more solid and perma- nent bridges between companies, research institutions, and the health system. This also reinforces the importance of knowledge developed in research institutions to increase the dynamics of the health industrial complex 7 , particularly its biotechnological components, like medicines, vaccines, and diagnostic devices.

The analysis also points to important measures for increasing the dynamics of the innovation system in health. There is also evidence that the relationships of health research groups prioritize three types of key players: (1) government institutions, especially those providing health services, like hospitals; (2) relations between teaching institutions and those specializing in $\mathrm{R} \& \mathrm{D}$, in practice involving "internal" relations in the academic community; (3) relations with sectors specializing in the production of health inputs, like medicines, fine chemicals, and medical and dental materials. A more detailed analysis of the evolution in these relations - disaggregated by region and specialty - can identity specificities, potentialities, and bottlenecks, with important implications for the formulation of policies to induce innovative processes within the health industrial complex.

\section{Contributors}

M. A. Vargas participated in the article's conception and design, data collection, analysis, and interpretation, writing and critical revision of the content, and approval of the final version for publication. J. Britto made a substantial contribution to the article's conception and design, data analysis and interpretation, critical revision of the intellectual content, and approval of the final version for publication.

\section{Acknowledgments}

The authors wish to thank the anonymous peer reviewers for their pertinent suggestions and criticisms. However, we take full responsibility for any errors or omissions.

\section{References}

1. Albuquerque EM, Souza SGA, Baessa AR. Pesquisa e inovação em saúde: uma discussão a partir da literatura sobre economia da tecnologia. Ciênc Saúde Coletiva 2004; 9:277-94.

2. Gelijns AC, Rosemberg N. The changing nature of medical technology development. In: Rosemberg N, Gelijns AC, Dawkins H, editors. Sources of medical technology: universities and industry. Washington DC: National Academy Press; 1995. p. 3-14.

3. Britto J, Vargas MA, Gadelha C, Costa L. Capacitação científico-tecnológica e articulação entre grupos de pesquisa na saúde. Rev Saúde Pública 2012; 46:41-50.

4. Guimarães R. Desafios da pós-graduação em saúde humana no Brasil. Rev Saúde Pública 2011; 45:1-13. 
5. Guimarães JA. A pesquisa médica e biomédica no Brasil: comparações com o desempenho científico brasileiro e mundial. Ciênc Saúde Coletiva 2004; 9:303-27.

6. Gadelha CAG. O complexo industrial da saúde e a necessidade de um enfoque dinâmico na economia da saúde. Ciênc Saúde Coletiva 2003; 8:521-35.

7. Gadelha CAG, Vargas MA, Maldonado J, Barbosa P, Costa L. A dinâmica do sistema produtivo da saúde: inovação e complexo econômico-industrial. Rio de Janeiro: Editora Fiocruz; 2012.

\section{Resumo}

A caracterização da infraestrutura científica e tecnológica na área da saúde e das suas formas de articulação com a base produtiva representam elementos centrais na compreensão da dinâmica de inovação em saúde. Este estudo faz uma análise exploratória sobre as potencialidades e limitações associadas às capacitações científicas e tecnológicas na área da saúde no Brasil e as formas de articulação entre a base científica e a base produtiva em saúde. A análise aponta para o crescimento expressivo da produção bibliográfica com circulação internacional no campo da saúde, particularmente em determinadas áreas como farmácia, saúde coletiva, genética, morfologia, fisiologia e microbiologia. Além disso, observa-se um crescimento expressivo dos grupos de pesquisa com relacionamentos como setor produtivo em áreas selecionadas da saúde. Destaca-se a importância da construção de pontes mais sólidas e permanentes entre empresas, instituições de pesquisa e sistema de saúde, articulando-se o conhecimento desenvolvido em instituições de pesquisa à dinamização da base produtiva em saúde.

Pesquisa Científica e Desenvolvimento Tecnológico; Políticas e Cooperação em Ciência, Tecnologia e Inovação; Indicadores de Produção Científica; Desenvolvimento Sustentável; Inovação
8. Vargas MA, Gadelha C, Maldonado J, Costa L. Inovação na indústria química e biotecnológica em saúde: em busca de uma agenda virtuosa. Rev Saúde Pública 2012; 46:37-40.

9. Albuquerque EM, Cassiolato JE. As especificidades do sistema de inovação do setor saúde: uma resenha da literatura como introdução a uma discussão sobre o caso brasileiro. Belo Horizonte: Federação de Sociedades de Biologia Experimental; 2000. (Estudos FeSBE, 1).

\section{Resumen}

La caracterización de la infraestructura científica y tecnológica en el área de la salud, y de sus formas de coordinación con el tejido productivo, representan elementos centrales en la comprensión de la dinámica de innovación en salud. Este estudio realiza un análisis exploratorio sobre las potencialidades y limitaciones asociadas a las capacitaciones científicas y tecnológicas en el área de la salud en Brasil, y las formas de colaboración entre la base científica y productiva en salud. El análisis apunta al crecimiento expresivo de la producción bibliográfica con difusión internacional en el campo de la salud, particularmente en determinadas áreas como farmacia, salud colectiva, genética, morfología, fisiología y microbiología. Asimismo, se observa un crecimiento expresivo de los grupos de investigación con relaciones en el sector productivo en áreas seleccionadas de la salud. Se destaca la importancia de la construcción de puentes más sólidos y permanentes entre empresas, instituciones de investigación y sistema de salud, colaborando el conocimiento desarrollado en instituciones de investigación con la dinamización de la base productiva en salud.

Investigación Científica y Desarrollo Tecnológico; Políticas y Cooperación en Ciencia, Tecnología e Innovación; Indicadores de Producción Científica; Desarrollo Sostenible; Innovación
Submitted on 15/Dec/2014

Final version resubmitted on $01 / \mathrm{Feb} / 2016$

Approved on 12/Feb/2016 